Jurnal Ners Volume 4 Nomor 1 Tahun 2020 Halaman 68 - 74

JURNAL NERS

Research \& Learning in Nursing Science

\title{
GAMBARAN STATUS GIZI PADA REMAJA PUTRI DI SMAN 1 BANGKINANG KOTA TAHUN 2019
}

\author{
Zurrahmi Z.R \\ Universitas Pahlawan Tuanku Tambusai \\ Zurrahmi10@gmail.com
}

\begin{abstract}
Abstrak
Status gizi remaja sangat penting untuk menunjang tumbuh kembang. Status gizi yang optimal akan membentuk remaja yang sehat dan produktif. Permasalahan yang muncul adalah gizi kurang dan lebih. Gizi kurang dapat mengakibatkan penurunan prestasi akademik dan mengakibatkan gangguan sistem reproduksi yang berdampak buruk di kemudian hari. Tujuan penelitian ini adalah untuk mengetahui Gambaran status gizi pada remaja putri di SMAN 1 Bangkinang Kota Tahun 2019. Jenis penelitian ini adalah deskriptif, untuk mengetahui gambaran status gizi pada remaja putri di SMAN 1 Bangkinang Kota tahun 2019. Populasi dalam penelitian ini adalah seluruh siswi di SMAN 1 Bangkinang kota tahun 2019 sebanyak 80 Siswi. Teknik pengumpulan data dengan menggunakan teknik random sampling. Analisa data yang digunakan dalam penelitian ini adalah analisa Univariate. Hasil penelitian menunjukkan status gizi remaja putri dengan persentase sebesar $70 \%$ dalam kategori normal. Berdasarkan karateristik umur remaja putri SMA N 1 Bangkinang yang menjadi responden dalam penelitian ini yaitu 80 responden, yang terdiri dari kelas X, XI, dan XII dari umur 15 tahun hingga umur 17 tahun berdasarkan standar IMT menunjukkan rata-rata 20,14\% yang masuk dalam kategori normal. Berdasarkan tabulasi status gizi pada remaja putri SMA N 1 Bangkinang, sebagian besar menunjukkan sebanyak 56 responden masuk dalam kategori normal. Saran dalam penelitian ini adalah Bagi remaja putri diharapkan memperhatikan pola makan yang sesuai dengan gizi seimbang guna tercapainya status gizi yang baik, sehingga dapat menunjang kegiatan pembelajaran sehari-hari terutama untuk proses tumbuh kembang.
\end{abstract}

Kata kunci : : Status Gizi, Remaja Putri

@ Jurnal Ners Prodi Sarjana Keperawatan \& Profesi Ners FIK UP 2020

$\square$ Corresponding author :

Address : Jl. Tuanku Tambusai No. 23 Bangkinang

Email : Zurrahmi10@gmail.com

Phone : 085265992150 


\section{PENDAHULUAN}

Remaja mempunyai kebutuhan nutrisi yang spesial, karena pada saat tersebut terjadi pertumbuhan yang pesat dan terjadi perubahan kematangan fisiologis sehubungan dengan timbulnya pubertas. Perubahan pada masa remaja akan mempengaruhi kebutuhan, absorbsi, serta cara penggunaan zat gizi. Hal ini disertai dengan pembesaran organ dan jaringan tubuh yang cepat.Perubahan hormonal yang menyertai pubertas juga menyebabkan banyak perubahan fisiologis yang memengaruhi kebutuhan gizi pada remaja (Aryani, 2012).

Energi dan protein yang dibutuhkan remaja lebih banyak dari pada orang dewasa, begitu juga vitamin dan mineral.Seorang remaja laki-laki yang aktif membutuhkan 3.000 kalori atau lebih perhari untuk mempertahankan berat badan normal. Seorang remaja putri membutuhkan 2.000kalori perhari untuk mempertahankan badan agar tidak gemuk. Vitamin B1, B2 dan B3 penting untuk metabolism karbohidrat menjadi energi, asam folat dan vitamin B12 untuk pembentukan sel darah merah, dan vitamin A untuk pertumbuhan jaringan. Sebagai tambahan, untuk pertumbuhan tulang dibutuhkan kalsium dan vitamin D yang cukup.Vitamin A, C dan E penting untuk menjaga jaringan-jaringan baru supaya berfungsi optimal.Dan yang amat penting adalah zat besi terutama untuk perempuan dibutuhkan dalam metabolism pembentukan sel-sel darah merah.(Husaini, 2006).
Berdasarkan data yang diperoleh dari World Health Organization (WHO) pada tahun 2016, status gizi pada remaja merupakan salah satu masalah gizi yang masih menjadi masalah kesehatan masyarakat terutama di negara berkembang. Survei prevalensi status gizi yang dilakukan WHO dari tahun 2010-2014 menunjukkan angka $48,8 \%$ terhadap insiden status gizi kurang secara global.

Lebih dari sepertiga $(36,1 \%)$ anak usia sekolah di Indonesia menderita gizi kurang (LIPI, 2004). Berdasarkan data FAO (2006), sekitar 854 juta orang di dunia menderita kelaparan kronis dan 820 juta diantaranya berada di Negara berkembang. Dari jumlah tersebut, 350-450 juta atau lebih dari 50\% di antaranya adalah anak-anak, dan 13 juta di antaranya berada di Indonesia. (Unilever, PT 2007). Hasil SKRT (Survei Kesehatan Rumah Tangga) 2004, menunjukkan bahwa terdapat $18 \%$ anak usia sekolah dan remaja umur 5-17 tahun berstatus gizi kurang.

Menurut data Kementerian Kesehatan Republik Indonesia (2016), kelompok umur 12-18 tahun penilaian status gizi berdasarkan IMT, prevalensi nasional kurus pada remaja putri umur 12-18 tahun adalah 7,5\% terdiri dari $1,8 \%$ sangat kurus dan $5,7 \%$ kurus. Sebanyak 17 provinsi dengan prevalensi anak sangat kurus (IMT/U) diatas prevalensi nasional yaitu Sumatera Utara sebesar 2,0\%, Riau sebesar 2,1\%, Jambi sebesar 2,3\%, Jawa Tengah sebesar 2,6\%, Jawa Timur 
sebesar 1,9\%, Bali sebesar $1,9 \%$, Nusa Tenggara Barat sebesar 3,2\%, Nusa Tenggara Timur sebesar 5,2\%, Kalimantan Barat sebesar 2,0\%, Kalimantan Selatan sebesar 4,0\%, Sulawesi Tengah sebesar 2,1\%, Sulawesi Tenggara sebesar 2,3\%, Sulawesi Barat sebesar 4,8\%, Maluku sebesar 3,6 \%, Papua Barat sebesar 3,3\%, dan Papua sebesar 4,7

Untuk prevalensi berat badan obesitas pada remaja puteri berdasarkan data Kementerian Kesehatan Republik Indonesia (2016) adalah sebesar 5,2\% dan prevalensi berat badan normal sebesar $87,3 \%$.

Di Provinsi Riau prevalensi sangat kurus sebesar 2,1\% dan prevalensi kurus sebesar 2,8\% untuk total prevalensi remaja putri sangat kurus dan kurus adalah sebesar $4,9 \%$. Sedangkan untuk obesitas 3,8\% dan normal 91,3\%.

Berdasarkan data penelitian dan pengembangan Departemen Kesehatan, penilaian status gizi remaja berdasarkan IMT/U Kabupaten Kampar Underweight dengan persentase $22.1 \%$, Stunting dengan persentase $27.0 \%$ Wasting dengan persentase $14.4 \%$ dan Gemukdengan persentase $4.1 \%$.

Berdasarkan hasil studi pendahuluan yang dilakukan di SMAN 1 Bangkinang dengan mengukur tinggi badan dengan berat badan siswa di SMAN 1 Bangkinang yang berjumlah 210 siswa, penulis mengambil survey awal sebanyak 30 siswi, didapatkan bahwa ada 24 siswi dengan persentase $80 \%$ yang mengalami gizi Underweight dan 1 siswi dengan persentase $3,33 \%$ memiliki gizi Normal, dan siswi yang mengalami gizi Overweight sebanyak 3 siswi dengan persentase $10 \%$ serta hanya 2 siswi yang bergizi Obesitas dengan persentase 6,66\%.

Dari pengamatan langsung di sekolah SMA Negeri 1 Bangkinang, terdapat beberapa remaja putri yang memiliki tubuh tidak proporsioanal, ada yang tinggi tetapi kurus dan ada yang pendek tetapi gemuk. Beberapa dari mereka bahkan memiliki pipi dan mata cekung, pembengkakan di bagian tubuh tertentu seperti perut, wajah atau kaki. Mereka juga tampak cenderung tampak pucat atau lelah, kurang bersemangat dan mudah ngantuk. Beberapa faktor yang menyebabkan hal tersebut adalah adanya remaja putri yang terlalu menjaga berat badan dengan mengikuti diet, faktor ekonomi, memiliki nafsu makan yang banyak, tidur tidak teratur, kurangnya pengetahuan remaja akan pentingnya gizi di masa pertumbuhan, dan lain sebagainya.

Selama ini masalah kesehatan remaja kurang mendapat perhatian serius, karena remaja secara umum tidak mudah terserang penyakit daripada anak-anak dan orangtua. Keadaan status gizi remaja pada umumnya dipengaruhi oleh pola konsumsi makan yang berakibat pada rendahnya tingkat konsumsi zat gizi. Hal ini disebabkan oleh keterbatasan makanan atau membatasi sendiri makanannya, karena faktor ingin langsing, hanya sedikit remaja yang merasa puas 
dengan tubuhnya. Sedangkan ukuran tubuh, usia, dan status kesehatan remaja putri kurang terperhatikan.

Berdasarkan uraian latar belakang diatas penulis tertarik melakukan penelitian dengan judul "Gambaran status gizi pada remaja putri di SMAN 1 Bangkinang Kota Tahun 2019".

\section{METODOLOGI PENELITIAN}

Jenis penelitian ini adalah deskriptif, untuk mengetahui gambaran status gizi pada remaja putri di SMAN 1 Bangkinang Kota tahun 2019. Penelitian ini akan dilakukan di SMAN 1 Bangkinang Kota pada bulan November 2019. Sampel dalam penelitian ini adalah siswi di SMAN 1 Bangkinang Kota tahun 2019 sebanyak 80 siswi. Analisa data yang digunakan dalam penelitian ini adalah analisa univariat dan analisa bivariat.

\section{HASIL PENELITIAN}

Pada bab ini akan disajikan hasil penelitian yang telah dilakukan pada 80 orang responden dengan menggunakan analisa univariat yang akan dijabarkan dalam bentuk tabel distribusi frekuensi sebagai berikut:

A. Karakteristik Responden Berdasarkan Umur dan Status Gizi

1. Umur

Tabel 4.1. Distribusi Frekuensi Responden Berdasarkan Umur Remaja Putri di SMAN 1 Bangkinang Kota Tahun 2019

\begin{tabular}{cccccc}
\hline No. & Kelas & $\begin{array}{c}\text { Rata-rata } \\
\text { Umur } \\
\text { (Tahun) }\end{array}$ & $\begin{array}{c}\text { Jumlah } \\
\text { Siswi }\end{array}$ & Persentase & Rata-rata IMT \\
\hline 1. & $\mathrm{X}$ & 15 & 35 & $43,75 \%$ & 20,14 \\
2. & $\mathrm{XI}$ & 16 & 25 & $31,25 \%$ & 20,41 \\
3. & XII & 17 & 20 & $25 \%$ & 19,41 \\
\hline & Total & & 80 & $100 \%$ & 20,14 \\
\hline
\end{tabular}

Dari tabel $4.1 \mathrm{di}$ atas dapat diketahui bahwa dari 80 responden yang terdiri dari kelas X, XI, dan XII dari umur 15 tahun hingga umur 17 tahun memiliki rata-rata standar IMT sebesar 20,14 (Normal).

2. Status Gizi

Tabel 4.2. Distribusi

Frekuensi

Responden Berdasarkan

Status Gizi Remaja Putri di SMAN 1 Bangkinang Kota Tahun 2019

\begin{tabular}{ccccc}
\hline No. & Status Gizi & Frekuensi (orang) & Persentase (\%) & IMT \\
\hline 1. & Underweight & 16 & $20 \%$ & $17,55 \%$ \\
2. & Normal & $\mathbf{5 6}$ & $\mathbf{7 0} \%$ & $\mathbf{2 0 , 4 1} \%$ \\
3. & Overweight & 5 & $6,25 \%$ & $23,94 \%$ \\
4. & Obesitas & 3 & $3,75 \%$ & $25,48 \%$ \\
\hline & Total & $\mathbf{8 0}$ & $\mathbf{1 0 0 \%}$ & $\mathbf{2 0 , 1 4 \%}$ \\
\hline
\end{tabular}

Dari tabel 4.2. dapat diketahui bahwa dari 80 responden, mayoritas memiliki badan normal yaitu sebanyak 56 orang dengan persentase $70 \%$ dan standar IMT sebesar $20,41 \%$.

\section{B. Tabulasi Status Gizi Berdasarkan Umur}

Tabel 4.3. Status Gizi Remaja Putri Di SMAN 1 Bangkinang Kota Tahun 2019 Berdasarkan Umur

\begin{tabular}{|c|c|c|c|c|c|c|c|c|c|}
\hline \multirow{2}{*}{\multicolumn{2}{|c|}{$\begin{array}{l}\text { No. Kelas Umur } \\
\text { (Than) }\end{array}$}} & & \multicolumn{2}{|c|}{ Normal \% } & \multicolumn{2}{|c|}{ Gemulk \% } & \multicolumn{2}{|c|}{ Obesiths \% Tote } \\
\hline & & 5 & 14,3 & 24 & 68,6 & 3 & 8,6 & 3 & $8,6 \quad 35$ \\
\hline 2. XI & 16 & 6 & 24 & 17 & 68 & 2 & 8 & . & 25 \\
\hline XII & 17 & 5 & 25 & 15 & 75 & . & . & . & . 20 \\
\hline \multicolumn{2}{|c|}{ Total } & 16 & . & 56 & . & 5 & . & 3 & .80 \\
\hline
\end{tabular}


Dari tabel 4.3 di atas dapat diketahui dari 80 responden bahwa pada kelas $\mathrm{X}$ dengan umur rata-rata berumur 15 tahun yang berjumlah 35 responden, sebanyak 5 orang dengan persentase $14,3 \%$ dalam kategori kurus, 24 orang dengan persentase $68,6 \%$ dalam kategori normal, 3 orang dengan persentase $8,6 \%$ dalam kategori gemuk, dan 3 orang dengan persentase $8,6 \%$ dalam kategori obesitas. Pada kelas XI dengan umur ratarata berumur 16 tahun yang berjumlah 25 responden sebanyak 6 orang dengan persentase $24 \%$ dalam kategori kurus, 17 orang dengan persentase $68 \%$ dalam kategori normal, 2 orang dengan persentase $8 \%$ dalam kategori gemuk, dan untuk kategori obesitas pada kelas XI tidak. Pada kelas XII dengan umur ratarata berumur 17 tahun yang berjumlah 20 responden sebanyak 5 orang dengan persentase $25 \%$ dalam kategori kurus, 15 orang dengan persentase $75 \%$ dalam kategori normal, untuk kategori gemuk dan kategori obesitas pada kelas XII tidak ada.

\section{PEMBAHASAN}

Dari hasil penelitian ini menunjukkan bahwa rata-rata umur remaja putri di SMA N 1 Bangkinang masuk dalam remaja pertengahan. Umur pada remaja putri di SMA $\mathrm{N} 1$ Bangkinang terdiri dari umur 15 tahun sampai dengan umur 17 tahun. Hal ini sesuai dengan definisi remaja menurut Word Healt
Organization (WHO) mengenai batasan remaja yaitu dalam rentang remaja awal sampai remaja akhir (infodatin, 2016).

Usia remaja menurut Aryani (2010) dibagi ke dalam tiga bagian yaitu masa remaja awal (10-13 tahun). Masa remaja awal ditandai dengan percepatan pertumbuhan dan pematangan fisik, sehingga sebagian besar energi intelektual dan emosional pada masa remaja awal ini ditargetkan pada penilaian kembali dan restrukturisasi dari jati diri. Selain itu penerimaan kelompok sebaya sangatlah penting, dengan tidak dipandang beda adalah motif yang mendominasi banyak perilaku sosial remaja awal. Masa remaja pertengahan (14-16 tahun) masa remaja menengah ditandai dengan hampir lengkapnya pertumbuhan pubertas, timbulnya keterampilanketerampilan berpikir yang baru, peningkatan pengenalan terhadap datangnya masa dewasa dan keinginan untuk memapankan jarak emosional dan psikologis dengan orang tua, sedangkan masa remaja akhir (17-19 tahun) ditandai dengan persiapan untuk peran sebagai seorang dewasa, termasuk kalasifikasi dari tujuan pekerjaan dan internalisasi suatu sistem nilai pribadi.

Berdasarkan karateristik umur remaja putri SMA N 1 Bangkinang yang menjadi responden dalam penelitian ini yaitu sebanyak 80 orang yang terdiri dari umur 15 tahun yaitu sebanyak 35 orang $(43,75 \%)$, umur 16 tahun yaitu hanya sebanyak 25 orang $(31,25 \%)$, umur 17 tahun yaitu sebanyak 20 orang (25 
$\%)$. Sebagian besar terdapat pada umur 15 tahun yaitu sebanyak 35 orang $(43,75 \%)$.

Berdasarkan Status Gizi yang didasari dari IMT/U BB dan TB dapat digunakan untuk menilai status gizi dengan IMT. IMT merupakan parameter untuk menilai status gizi secara lebih terstruktur. Sumber Kemenkes RI (2010) mengatakan IMT direkomendasikan sebagai indikator yang baik untuk menentukan status gizi remaja, BB dan TB dapat digunakan untuk menilai status gizi dengan IMT yang terkait dengan umurnya, karena dengan perubahan umur terjadi perubahan komposisi tubuh. Penelitian ini menggunakan parameter IMT untuk menggambarkan status gizi remaja putri. masuk dalam kategori ideal (normal). Hasil penelitian ini menunjukkan bahwa remaja yang kurus sebesar 20\%, normal sebesar 70\%, , kegemukan sebesar 6,25\% obesitas sebesar 3,75\%. Hasil tersebut menunjukkan bahwa remaja putri SMAN 1 Bangkinang Kota dengan persentase sebesar $70 \%$ dalam kategori normal, hal ini berdasarkan hasil perhitungan dan penelitian yang dilakukan di SMAN 1 Bangkinang Kota dengan jumlah responden sebesar 80 responden yang terbagi dari kelas X, XI, dan XII, pada kelas $\mathrm{X}$ dengan rata-rata umur 15 tahun berjumlah 35 siswi memiliki standar (IMT) sebesar $20,14 \%$ (termasuk dalam kategori normal), sedangkan kelas XI dengan rata-rata umur 16 tahun berjumlah 25 siswi memiliki standar (IMT) sebesar $20.41 \%$ (termasuk dalam kategori normal), dan untuk kelas XII dengan rata-rata umur 17 tahun berjumlah 20 siswi memiliki standar (IMT) sebesar 19,41\% (termasuk dalam kategori normal).

Pada remaja yang mengalami obesitas, kegemukan maupun kurus, faktor utamanya adalah pola olahraga yang tidak teratur dan remaja terlalu banyak makan menyebabkan energi yang keluar tidak sesuai dengan kalori yang masuk bagi remaja yang mengalami kegemukan dan obesitas sedangkan bagi remaja putri yang kurus disebabkan pola makan yang tidak seimbang dengan kebutuhan tubuh atau kurangnya nafsu makan. Faktorfaktor lainnya yaitu adanya tingkat sosial ekonomi, lingkungan, pola makan, dan perubahan gaya hidup yang salah diantaranya pola makan tinggi lemak dan rendah serat (Adriyani, 2012).

Berdasarkan tabulasi silang status gizi pada remaja putri SMA N 1 Bangkinang, sebagian besar menunjukkan sebanyak 56 responden masuk dalam kategori normal yang merupakan nilai tertinggi pada remaja pertengahan dan sebanyak 3 responden masuk dalam kategori obesitas yang merupakan nilai terendah pada remaja pertengahan. Usia ini termasuk kategori remaja pertengahan, karena pada fase ini remaja berfokus pada keterampilan-keterampilan berfikir yang baru mengenai datangnya masa dewasa dan memapankan jarak emosional dan psikologis dengan orang tua. Menurut Arisman (2010), masa remaja merupakan masa terjadinya perubahan-perubahan untuk pertumbuhan. Pertumbuhan yang cepat biasanya diiringi oleh 
pertumbuhan aktivitas fisik sehingga kebutuhan zat gizi akan naik pula sehingga sebagian besar status gizi remaja pertengahan dalam kategori normal dan permasalahan status gizi hanya sedikit.

\section{KESIMPULAN}

1. Berdasarkan karateristik umur remaja putri SMA N 1 Bangkinang yang menjadi responden dalam penelitian ini yaitu 80 responden, yang terdiri dari kelas X, XI, dan XII dari umur 15 tahun hingga umur 17 tahun berdasarkan standar IMT menunjukkan rata-rata $20,14 \%$ yang masuk dalam kategori normal.

2. Berdasarkan status gizi remaja putri SMA N 1 Bangkinang, mayoritas memiliki badan normal yaitu sebanyak 56 orang dengan persentase $70 \%$ dan standar IMT sebesar 20,41\%.

3. Berdasarkan tabulasi status gizi pada remaja putri SMA N 1 Bangkinang, sebagian besar menunjukkan sebanyak 56 responden masuk dalam kategori normal yang merupakan nilai tertinggi pada remaja pertengahan dan sebanyak 3 responden masuk dalam kategori obesitas yang merupakan nilai terendah pada remaja pertengahan.

\section{REFERENSI}

Adriyani, M., Wirjatmadi B, (2012). Peran Gizi dalam Siklus Kehidupan, Prenamedia Group, Jakarta.
Aryani, (2012). Kesehatan Remaja Problem dan Solusinya. Jakarta, Penerbit Salemba Medika

Depkes RI, (2010). Kategori Usia Remaja. Jakarta, Direktorat Kesehatan.

Dinkes Kabupaten Kampar, (2017). Jumlah Status Gizi Pada Remaja. Kampar, Dinkes

Kemenkes RI, (2016). Hasil Pemantauan Status Gizi (PSG) Tahun 2016. Jakarta,Direktorat Gizi Masyarakat Direktorat Jenderal Kesehatan Masyarakat Kementerian Kesehatan 2017.

World Health Organization, (2016). Status Gizi Pada Remaja. Diakses pada tanggal 6 Desember 2018

(WHO, (2014), Kategori IMT, http://chinue. Word Press. com/2009/03/14/.Diperoleh pada tanggal 4 Desember 2013). 
75| GAMBARAN STATUS GIZI PADA REMAJA PUTRI DI SMAN 1 BANGKINANG KOTA TAHUN 2019 